\title{
Dinamika Kelompok Tani Hutan pada Pengelolaan Hutan Produksi Bersama Masyarakat di Perum Perhutani Unit I Provinsi Jawa Tengah
}

\author{
Factors that Influence Group Dynamic of Forest Farmers Group in collaborative \\ forest management with local people in the forest production areas of State Forestry \\ Corporation (Perum Perhutani) Unit I in the Province of Central Java)
}

\author{
Suwignya Utama ${ }^{1}$, Sumardjo $^{3}$, Djoko Susanto ${ }^{3}$, Darwis S. Gani \\ ${ }^{1}$ Departemen Kehutanan RI \\ ${ }^{2}$ Departemen Sains Komunikasi dan Pengembangan Masyarakat, \\ Fakultas Ekologi Manusia, Institut Pertanian Bogor \\ ${ }^{3}$ Pusat Penelitian Gizi Departemen Kesehatan
}

\begin{abstract}
The collaboration on managing forest resource involves two main actors such as State Forestry Corporation (Perum Perhutani) and forest farmers groups. The objectives of this study are: (1) to explore the conditions of factors that influence group dynamics of forest farmers group $(F F G) ;(2)$ to explore the condition of group dynamic of forest farmers group and to identify several factors influence the group dynamic (3) to formulate a model of group dynamic of FFG. Several variables are included in this study such as potency of individual farmers, effectiveness of empowerment process, role of facilitators, effectiveness of forest farmers' group leadershi, environmental supports and group dynamic of FFG. The locations of the study are in three forest districts area of East Pekalongan, South Kedu and Gundih. The preliminary study was carried out in January 2008, and field survey had been accomplished from July to August 2008. Populations of the study are forest villagers around state forest areas in three selected locations of 889.407 families. Method in this study is survey with questionnaire. Respondents of 408 farmers were selected through multistage cluster sampling with disproportional number of respondents each location. The research data were processed with descriptive analysis and structural equation modeling (SEM) with LISREL 8.72. The conclusions of the study are: (1) The condition of effectiveness of forest farmers' group leadership low (score 62); the condition of environmental support is low (score 62) and the condition of facilitators' role is also low(score 62); (2) Level of group dynamic of forest farmers' group is low. Factors that influence significantly on the low of group dynamic are the low effectiveness of forest farmers' group leadership, unfavorable environmental supports and low role of facilitators; (3) Model of effective group dynamic are influenced by effectiveness of forest farmers' group leadership, favorable environmental supports and role of facilitators. Whereas group dynamic consists of goal of the group, group structure and group function.
\end{abstract}

Keywords: Group Dynamic, Forest Villagers, Forest Farmers Group, Collaborative Forest Management, Social Forestry

\section{Pendahuluan}

Peluang masyarakat sekitar hutan untuk turut mengelola sumberdaya alam hutan semakin menguat sejalan dengan adanya pergeseran paradigma pengelolaan hutan. Paradigma baru pengelolaan sumberdaya hutan di Indonesia mengarah kepada pemanfaatan yang mampu memberikan manfaat secara lestari, produktif, efisien dan

\footnotetext{
${ }^{1}$ Korespondensi Penulis: 081318213902
} 
adil. Pengelolaan sumberdaya hutan bergeser dari sentralistik ke desentralistik, dari berbasis negara menjadi berbasis komunitas. Paradigma baru mengutamakan pengetahuan masyarakat yang kreatif dan dinamis sebagai suatu hasil proses belajar dari kehidupan sehari-hari (Suharjito et. al., 2000). Pendekatan pengelolaan hutan yang melibatkan masyarakat ini dikenal dengan kehutanan masyarakat (social forestry). Hal ini tercermin di dalam Undang-undang No. 41 Tahun 1999 tentang Kehutanan, yang menyatakan bahwa pengelolaan hutan dari sisi fungsi produksinya diarahkan menjadi pengelolaan yang berorientasi pada seluruh potensi sumberdaya kehutanan dan berbasis pada pemberdayaan masyarakat. Dalam Peraturan Menteri Kehutanan No. P.01/MENHUT-II/2004 disebutkan bahwa pemberdayaan masyarakat setempat di dalam dan atau di sekitar hutan dimaksudkan untuk meningkatkan kemampuan dan kemandirian masyarakat dalam pemanfaatan hutan dalam rangka social forestry. Tujuannya adalah untuk meningkatkan kesejahteraan masyarakat setempat dan terwujudnya pengelolaan hutan yang lestari.

Implikasi pendekatan kehutanan masyarakat adalah bahwa masyarakat sebagai pelaku utama dalam pengelolaan sumberdaya hutan. Sebagai pelaku utama, masyarakat harus mampu mengendalikan pembuatan keputusan tentang pengelolaan sumberdaya hutan. Dalam UU No. 16 tahun 2006 tentang Sistem Penyuluhan Pertanian, Perikanan dan Kehutanan tercantum bahwa pelaku utama dalam kegiatan kehutanan yaitu masyarakat di dalam dan di sekitar kawasan hutan. Menurut Sardjono (2004) penguatan modal manusia dalam bidang kehutanan diperlukan agar partisipasi dan kerjasama yang dibangun bersifat setara atau tidak ada dominasi satu pihak kepada pihak lain. Kesetaraan masyarakat sekitar hutan sebagai pelaku utama dalam pembangunan kehutanaan dengan pihak lain menjadi sangat penting agar mereka berperan secara optimal dalam pengelolaan sumberdaya hutan. Mulyadi (2008) juga menyatakan bahwa aspek yang paling berpengaruh terhadap keberhasilan rehabilitasi hutan dan lahan adalah faktor manusia diantaranya adalah kelembagaan organisasi kelompok tani.

Salah satu bentuk pemberdayaan terhadap masyarakat sekitar hutan yang efektif adalah melalui bentuk pemberdayaan kelompok. Pendekatan kelompok mempunyai kelebihan karena lebih luas daya jangkaunya, dan sesuai dengan budaya masyarakat pedesaan yang lebih komunal. Kelompok juga memiliki fungsi diantaranya sebagai wadah proses pembelajaran dan wahana dalam bekerjasama antar masyarakat. Thompson (1999) menekankan bahwa salah satu elemen kunci keberhasilan kehutanan masyarakat yaitu pengembangan organisasi (kelompok) lokal untuk mengelolaan hutan yang partisipatif. Dalam perspektif penyuluhan, Slamet (2003) menyatakan bahwa paradigma baru penyuluhan adalah melalui pendekatan kelompok. Materi penyuluhan yang disajikan melalui kelompok akan lebih efisien dan mempunyai konsekuensi dibentuknya kelompok-kelompok tani sehingga mendorong terjadinya interaksi antar petani dalam wadah kelompok itu. Interaksi antar petani dalam kelompok sangat penting sebab merupakan forum komunikasi yang demokratis di tingkat akar rumput. Forum kelompok merupakan forum belajar sekaligus forum pengambilan keputusan untuk memperbaiki nasib mereka sendiri. Melalui forum tersebut pemberdayaan ditumbuhkan yang akan berlanjut pada tumbuh dan berkembangnya kemandirian rakyat tani. Melalui kelompok-kelompok itu kepemimpinan di kalangan petani akan tumbuh dan berkembang melalui pembinaan penyuluh pertanian. 
Keberadaan kelompok tani bagi masyarakat sekitar hutan sudah ada sejak awalawal program kehutanan masyarakat diluncurkan oleh Perhutani tahun 1980-an. Beberapa penelitian menunjukkan bahwa kondisi dan kedudukan kelompok masih lemah dalam menjalankan perannya mengelola sumberdaya hutan bersama Perhutani. Oleh karena itu aspek kelompok tani hutan sangat penting diperhatikan dalam proses pemberdayaan. Pemberdayaan terhadap masyarakat sekitar hutan dengan memperhatikan kelembagaan kelompok tani harus dilakukan secara tepat agar kelompok dapat menjadi mitra sejajar dengan pihak Perhutani dalam mengelola sumberdaya hutan.

Pentingnya pendekatan kelompok dalam konteks penyuluhan mendorong penulis untuk mendalami permasalahan kelompok tani bagi masyarakat sekitar hutan. Tujuan penelitian ini adalah untuk: Mengungkap kondisi potensi sumberdaya individu petani, ketepatan proses pemberdayaan, peran SDM pemberdayaan, keefektifan kepemimpinan kelompok, dukungan lingkungan dan dinamika kelompok tani hutan; menjelaskan faktor-faktor yang berpengaruh terhadap dinamika kelompok tani hutan; dan menyusun model peningkatan dinamika kelompok tani hutan.

\section{Metode Penelitian}

Penelitian dilakukan di wilayah pengelolaan hutan Perum Perhutani Unit I Jawa Tengah, meliputi tiga KPH (Kesatuan Pemangkuan Hutan) yaitu KPH Pekalongan Timur, KPH Kedu Selatan dan KPH Gundih. Penelitian pendahuluan pada bulan Januari 2008, dan pengambilan data pokok dari responden dilakukan pada bulan Juli s.d Agustus 2008.

Populasi penelitian adalah jumlah keseluruhan kepala keluarga petani sekitar hutan yang tergabung dalam Kelompok Tani Hutan (KTH) pada tiga lokasi penelitian, yaitu sebanyak 853.407 orang petani sebagai kepala keluarga. Pengambilan sampel secara multistage cluster random sampling (gugus bertingkat secara acak) dengan jumlah sampel tidak proporsional (disproporsional). Jumlah sampel dengan presisi $\alpha=0,05$ atau tingkat kepercayaan 0,95 diperlukan 399,82 orang atau 400 orang. Sampel ditentukan 408 orang. Pengambilan sampel dari $3 \mathrm{KPH}$ dipilih secara acak masingmasih $2 \mathrm{BKPH}$, tiap BKPH dipilih masing-masing $2 \mathrm{LMDH}$, tiap LMDH dipilih masing-masing $3 \mathrm{KTH}$, tiap KTH dipilih petani responden 11-12 orang.

Jenis penelitian adalah survey yang mengambil sampel dari populasi dengan kuesioner sebagai alat pengambilan data pokok. Penelitian ini digunakan untuk maksud penelitian penjelasan (Explanatory Research) yaitu menjelaskan hubungan kausalitas antara peubah-peubah penelitian melalui pengujian hipotesis. Instrumen telah memenuhi validitas isi melalui evaluasi Tim Pakar dan validitas konstruk dengan telaah teori yang relevan. Uji reliabilitas instrumen dalam penelitian ini menggunakan metode Alpha Cronbach dengan kisaran nilai 0,60 (cukup reliabel) - 0,87 (sangat reliabel). Analisis data secara deskriptif dan analisis hubungan kausal. Pengolahan data deskriptif, data ordinal ditransformasi menjadi skala 100 (data interval) dan perhitungan rerata dengan bobot tiap lokasi penelitian karena sampel disproporsional. Analisis hubungan kausal menggunakan structural equation modelling (SEM) dengan Program Lisrel 8,72. Analisis dilakukan dengan pendugaan paramater, analisis model pengukuran, uji kecocokan keseluruhan model dan analisis model struktural. 


\section{Hasil Dan Pembahasan}

\section{Kondisi Potensi Sumberdaya Individu Petani}

Potensi sumberdaya individu petani meliputi luas lahan garapan, pengalaman berusahatani, umur, pendapatan keluarga, tanggungan keluarga, pendidikan formal, pendidikan non formal, motivasi berkelompok dan keinovatifan. Luas lahan garapan tiap keluarga petani rata-rata 1,25 ha di mana dua pertiganya dari lahan hutan berupa andil dan lahan di bawah tegakan hutan. Pengalaman berusaha tani rata-rata 21 tahun, dan 9 tahun terakhir mengolah lahan hutan. Umur rata-rata 43 tahun, dengan pendapatan keluarga per bulan rata-rata Rp 1.061.077,- sepertiganya berasal dari mengelola sumberdaya hutan. Pendapatan dari hutan bagi petani KPH Pekalongan Timur bahkan sebesar 74 persen dari pendapatan keluarga. Jumlah tanggungan keluarga berkisar $3-4$ orang. Pendidikan formal mayoritas (79\%) sampai SD. Pendidikan non formal yang diikuti petani termasuk jarang mengikuti pelatihan kehutanan. Motivasi berkelompok termasuk sedang, dan terdapat perbedaan yang nyata antar lokasi penelitian. Motivasi berkelompok petani di KPH Kedu Selatan relatif lebih tinggi dibandingkan dengan dua lokasi lainnya. Keinovatifan petani secara keseluruhan termasuk rendah, namun keinovatifan petani di KPH Kedu Selatan termasuk sedang dan berbeda nyata dengan dua lokasi lainnya (Tabel 1).

Tabel 1. Kondisi potensi sumberdaya individu petani sampel (X1) pada KPH Pekalongan Timur (A), KPH Kedu Selatan (B) dan KPH Gundih (C)

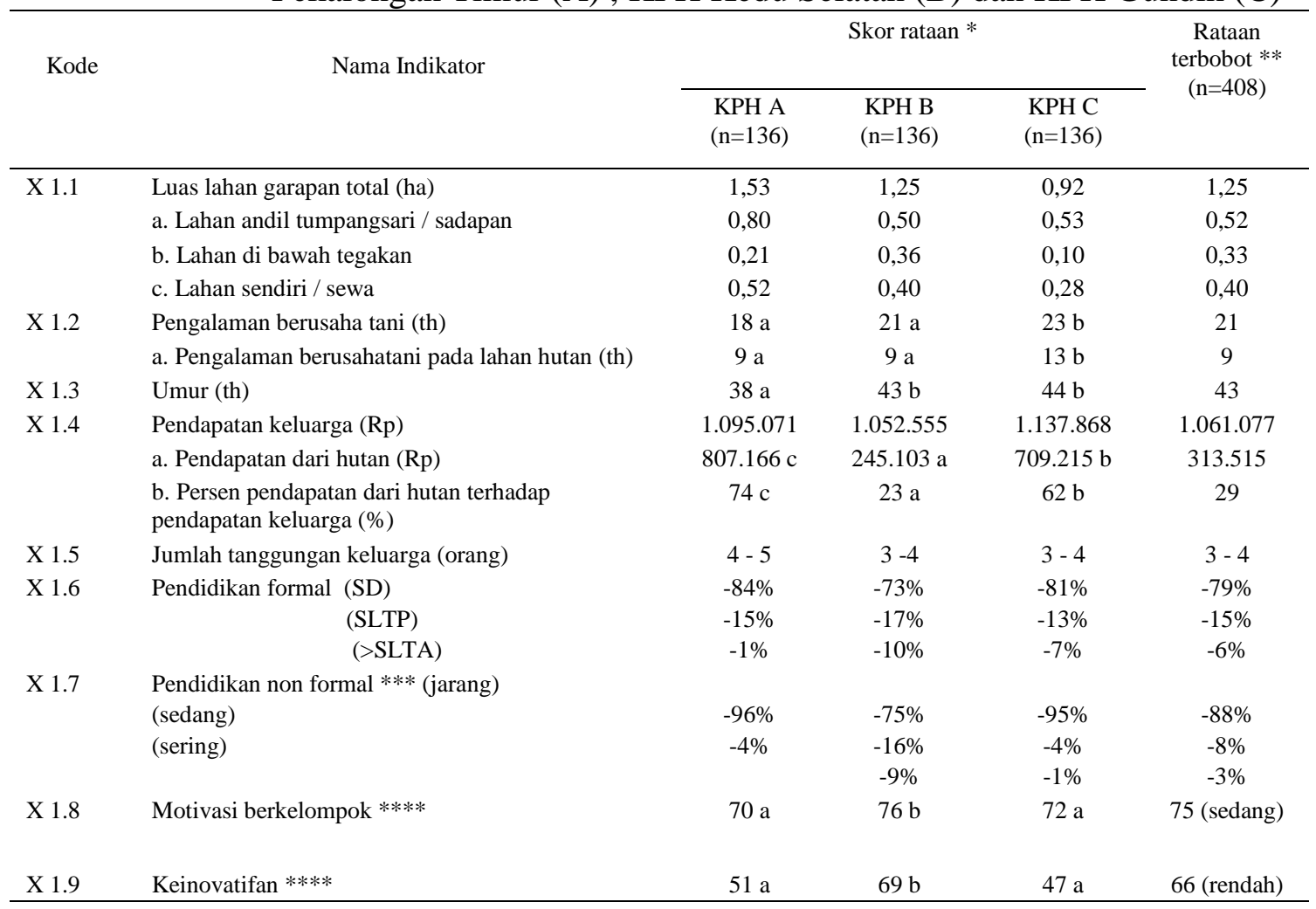

\footnotetext{
Keterangan :

* Angka yang diikuti oleh huruf yang sama tidak berbeda nyata pada taraf uji 0,05 (T-test)

** Bobot sampel : KPH A : KPH B :: KPH C = $1: 13: 1$

*** Keterangan = 1-3 kali (jarang); 4-6 kali (sedang); 7-10 kali (sering)

$* * * *$ Kategori : Rendah $=0-66,9 ;$ Sedang $=67,0-82,9 ;$ Tinggi $=83,0-100$
} 


\section{Kondisi Ketepatan Proses Pemberdayaan}

Ketepatan proses pemberdayaan berada dalam kategori 'rendah' dengan skor rataan sebesar 26. Ketepatan proses pemberdayaan menurut persepsi petani di KPH Kedu Selatan relatif lebih tinggi dan berbeda nyata dengan dua lokasi penelitian lainnya. Rendahnya ketepatan proses pemberdayaan terutama karena inisiatif dan tujuan program sudah ditentukan oleh Perhutani, proses penyadaran satu arah dengan materi menonjolkan teknis pengelolaan hutan, lembaga masyarakat yang berupa LMDH (Lembaga Masyarakat Desa Hutan) dan kelompok tani hutan (KTH) kebanyakan dibentuk oleh petugas, hak dan kewajiban para pihak sudah ditentukan oleh Perhutani, pemanfaatan ruang kelola kebanyakan sudah ditentukan dan proporsi bagi hasil juga sudah ditentukan oleh aturan dari Perhutani (Tabel 2).

\section{Kondisi Peran SDM Pemberdayaan}

Peran SDM pemberdayaan termasuk dalam kategori 'rendah' dengan skor rataan 62, dan terdapat perbedaan yang nyata diantara tiga lokasi penelitian. Peran SDM pemberdayaan pada KPH Kedu Selatan relatif lebih tinggi disusul KPH Gundih dan paling rendah kondisi di KPH Pekalongan Timur. Sumberdaya manusia pemberdayaan dalam penelitian ini adalah petugas Mandor Perhutani yang dalam kegiatan sehariharinya mendampingi dan berinteraksi langsung dengan petani hutan dalam kegiatan pengelolaan sumbedaya hutan oleh masyarakat. Menurut persepsi petani, Mandor adalah petugas Perhutani yang paling dekat dengan petani dalam mendampingi berbagai kegiatan pengelolaan sumberdaya hutan. Beberapa peran sumberdaya manusia pemberdayaan yang terlihat dalam kategori sedang yaitu mengembangkan partisipasi petani, mengorganisasikan petani dan kesetaraan status sosial dengan petani. Selanjutnya SDM pemberdayaan ini disebut juga sebagai pendamping. Rendahnya peran pendamping ini terutama disebabkan oleh lemahnya pendamping dalam mencari peluang pasar bagi kelompok, dan kurangnya pendamping membina hubungan dengan berbagai pihak yang terkait dengan program (Tabel 2).

\section{Kondisi Keeefektifan Kepemimpinan Kelompok}

Keefektifan kepemimpinan kelompok termasuk dalam kategori 'rendah' dengan skor rataan 62. Kepemimpinan kelompok meliputi peran pemimpin kelompok. perilaku kepemimpinan, dan gaya kepemimpinan. Menurut persepsi petani, kepemimpinan kelompok yang paling berpengaruh terhadap kehidupan mereka adalah pemimpin kelompok pada tingkat Kelompok Tani Hutan (KTH). Ada pemimpin kelompok pada tingkat LMDH di desa, namun kebanyakan petani kurang merasakan kepemimpinan pada tingkat LMDH. Dalam penelitian ini keefektifan kepemimpinan kelompok diukur pada kepemimpinan tingkat KTH tersebut. Rendahnya keefektifan kepemimpinan kelompok ditunjang oleh kurang optimalnya peran kepemimpinan kelompok, kurang optimalnya perilaku kepemimpinan dan lemahnya gaya kepemimpinan dalam kelompok. Dari tiga lokasi penelitian terdapat perbedaan yang nyata kondisi keefektifan kepemimpinan kelompok, di mana KPH Kedu Selatan termasuk relatif paling tinggi, disusul KPH Gundih dan paling rendah KPH Pekalongan Timur (Tabel 2). 
Tabel 2. Kondisi peubah-peubah penelitian pemberdayaan masyarakat sekitar hutan pada KPH Pekalongan Timur (A), KPH Kedu Selatan (B) dan KPH Gundih (C)

\begin{tabular}{|c|c|c|c|c|c|}
\hline \multirow{2}{*}{ Kode } & \multirow{2}{*}{ Nama Peubah Penelitian } & \multicolumn{3}{|c|}{ Skor rataan * } & \multirow{2}{*}{$\begin{array}{c}\text { Rataan } \\
\text { tertimbang } \\
(n=408)\end{array}$} \\
\hline & & $\begin{array}{l}\text { KPH A } \\
(n=136)\end{array}$ & $\begin{array}{l}\text { KPH B } \\
(n=136)\end{array}$ & $\begin{array}{l}\text { KPH C } \\
(\mathrm{n}=136)\end{array}$ & \\
\hline $\mathrm{X} 2$ & Ketepatan Proses Pemberdayaan & $24 \mathrm{a}$ & $27 \mathrm{~b}$ & $22 \mathrm{a}$ & 26 \\
\hline X3 & Peran SDM Pemberdayaan & $37 \mathrm{a}$ & $65 \mathrm{c}$ & $47 \mathrm{~b}$ & 62 \\
\hline $\mathrm{X} 4$ & Keefektifan Kepemimpinan Kelompok & $49 \mathrm{a}$ & $64 \mathrm{c}$ & $52 \mathrm{~b}$ & 62 \\
\hline $\mathrm{X} 5$ & Dukungan Lingkungan & $55 \mathrm{~b}$ & $63 \mathrm{c}$ & $52 \mathrm{a}$ & 62 \\
\hline $\mathrm{Y} 1$ & Dinamika Kelompok & $51 \mathrm{a}$ & $67 \mathrm{c}$ & $55 \mathrm{~b}$ & 65 \\
\hline
\end{tabular}

Keterangan :

* Angka yang diikuti oleh huruf yang sama tidak berbeda nyata pada taraf uji 0,05 (T-test)

Kategori: Rendah $=0-66,9 ;$ Sedang $=67,0-82,9 ;$ Tinggi $=83,0-100$

** Bobot sampel : KPH A : KPH B :: KPH C $=1: 13: 1$

\section{Kondisi Dukungan Lingkungan}

Kondisi dukungan lingkungan termasuk dalam kategori "rendah" dengan skor rataan sebesar 62. Dukungan lingkungan meliputi persepsi petani responden terhadap lingkungannya, akses lahan, potensi sumberdaya hutan, ketersediaan sarana produksi pertanian, pemasaran hasil, potensi modal sosial, pengembangan usaha, alternatif usaha, ketergantungan pada hutan, dan intervensi lingkungan sosial. Dari tiga lokasi penelitian, terdapat perbedaan yang nyata tentang kondisi dukungan lingkungan. Kondisi dukungan lingkungan di KPH Kedu Selatan relatif paling tinggi, disusul kondisi di KPH Pekalongan Timur dan paling rendah di KPH Gundih (Tabel 2).

\section{Kondisi Dinamika Kelompok}

Dinamika kelompok tani hutan secara umum termasuk kategori 'rendah' dengan skor rataan sebesar 65. Kondisi dinamika kelompok tani hutan berbeda secara nyata antar tiga lokasi penelitian. Dinamika kelompok tani hutan di KPH Kedu Selatan termasuk 'sedang'dengan skor rataan sebesar 67, sedangkan dinamika kelompok tani hutan di KPH Gundih termasuk rendah namun lebih baik dibandingkan kondisi di KPH Pekalongan Timur (Tabel 2).

Rendahnya dinamika kelompok terutama ditunjang indikator-indikator yang mempunyai nilai rendah yaitu tegangan kelompok, maksud tersembunyi dan perkembangan usaha kelompok. Kualitas suasana kelompok, keefektifan kelompok dan kekompakan kelompok termasuk 'sedang' dan relatif lebih baik dari indikator-indikator lainnya. Sesuai temuan di lapangan bahwa kelompok tani hutan kebanyakan terdiri dari para anggota yang rumahnya saling berdekatan, dengan suasana kekeluargaan yang masih terasa.

Dinamika kelompok diukur secara subyektif melalui persepsi petani responden terhadap kondisi kelompok tani hutan tempat mereka bergabung. Kelompok tani hutan (KTH) ini kebanyakan terbentuk berdasarkan kedekatan tempat tinggal, dan biasanya dalam satu dusun atau pedukuhan. Beberapa kelompok tani hutan bergabung di dalam 
naungan organisasi yang lebih tinggi atau LMDH (Lembaga Masyarakat Desa Hutan) pada tingkat desa. Para petani responden dalam kegiatan sehari-harinya lebih banyak berinteraksi di dalam kelompok tani hutan. Istilah KTH pada LMDH Wana Indah di BKPH Monggot, KPH Gundih dinamakan kelompok kerja (Pokja).

\section{Pendugaan Parameter Model Dinamika Kelompok Tani Hutan}

Pendugaan parameter-parameter penelitian dinamika kelompok tani hutan dilakukan dengan analisis Structural Equation Modelling (SEM) dengan Program Lisrel 8.72. Strategi permodelan yang digunakan dalam penelitian ini yaitu "Strategi Pengembangan Model" atau model development strategy (Hair et. al., 1998 diacu dalam Wijanto, 2008). Pendekatan ini dilakukan dengan melakukan spesifikasi model awal secara teoretis, mengumpulkan data 408 responden, pendugaan parameter model awal, analisis model pengukuran, respesifikasi model untuk mendapatkan model akhir dan evaluasi kecocokan model.

Hasil pendugaan model awal dinamika kelompok (Gambar 1) menunjukkan bahwa nilai $\mathrm{P}=0,000(0,05 \leq)$, nilai $\mathrm{RMSEA}=0,13(0,08 \leq)$, dan nilai $\mathrm{CFI}=0,86$ $(0,90 \leq)$. Ukuran kecocokan keseluruhan model lainnya yaitu $\mathrm{NFI}=0,85, \mathrm{NNFI}=0,86$, RFI $=0,84$. $I F I=0,86$ dan $\mathrm{GFI}=0,57$ yang semuanya $0,90 \leq$. Dengan kata lain model dinamika kelompok tani hutan di atas secara keseluruhan belum mempunyai kecocokan model yang baik. Model awal belum mampu menduga (estimasi) matriks kovariansi populasi, sehingga model perlu diperbaiki (respesifikasi).

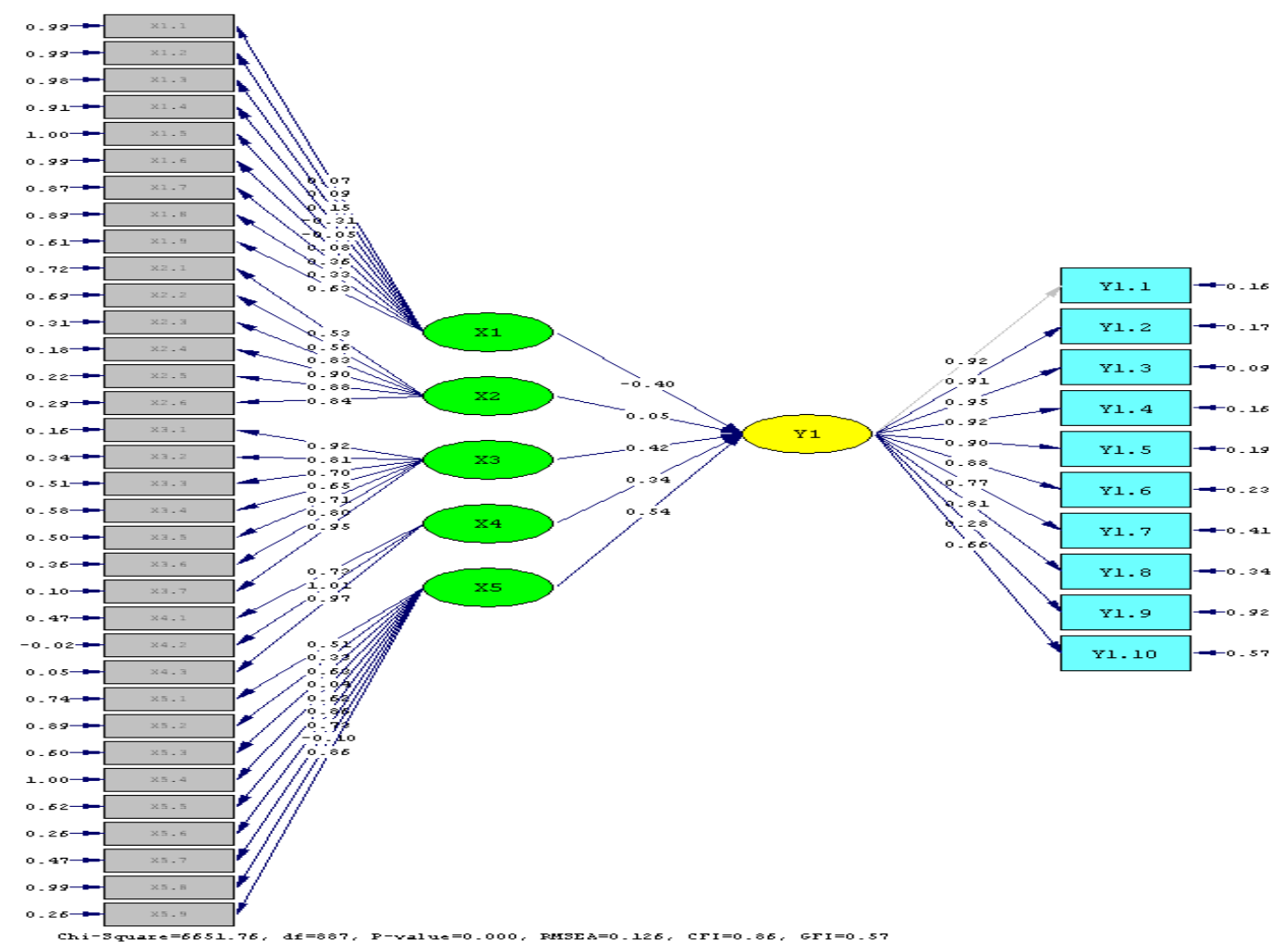

Gambar 1. Diagram lintasan Model Dinamika Kelompok Tani Hutan awal sebelum respesifikasi (Basic Model - Standardized Solution) 
Hasil pendugaan parameter model akhir setelah respesifikasi (Gambar 2) menunjukkan bahwa nilai $\mathrm{P}=0,055(\geq 0,05)$, nilai RMSEA $=0,058(\leq 0,08)$, dan nilai $\mathrm{CFI}=0,99(\geq 0,90)$. Ukuran kecocokan keseluruhan model lainnya yaitu $\mathrm{NFI}=0,98$, $\mathrm{NNFI}=0,99, \mathrm{RFI}=0,96$. IFI $=0,99$ dan $\mathrm{GFI}=0,91$ yang semuanya $\geq 0,90$, atau dengan kata lain model dinamika kelompok tani hutan di atas secara keseluruhan mempunyai kecocokan model yang baik. Model akhir mampu menduga (estimasi) matriks kovariansi populasi, atau hasil estimasi parameter model dapat diberlakukan terhadap populasi penelitian.

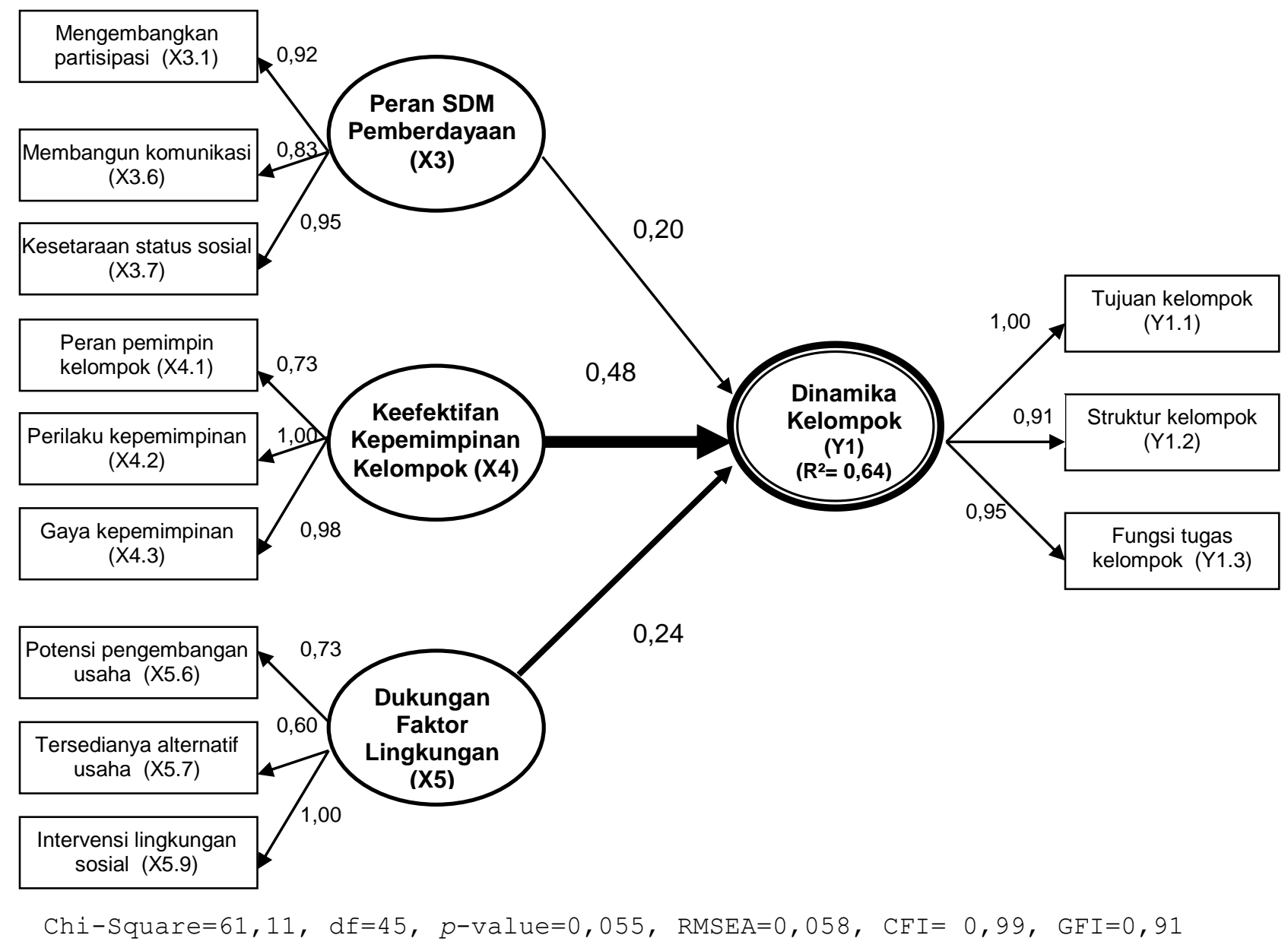

Gambar 2. Diagram lintasan Model Dinamika Kelompok Tani Hutan setelah respesifikasi (Basic Model - Standardized Solution)

Dengan nilai SLF atau muatan faktor standar yang menghubungkan indikator dengan peubahnya sebesar $\geq 0,50$ dan nilai- $\mathrm{t}>1,96$, maka indikator-indikator pada Gambar 2 termasuk valid sebagai pengukur peubahnya sehingga model (dinamika kelompok tani hutan) memenuhi persyaratan (Igbaria et. al. 1997, diacu dalam Wijanto (2008). 
Model persamaan struktural dinamika kelompok tani hutan yaitu :

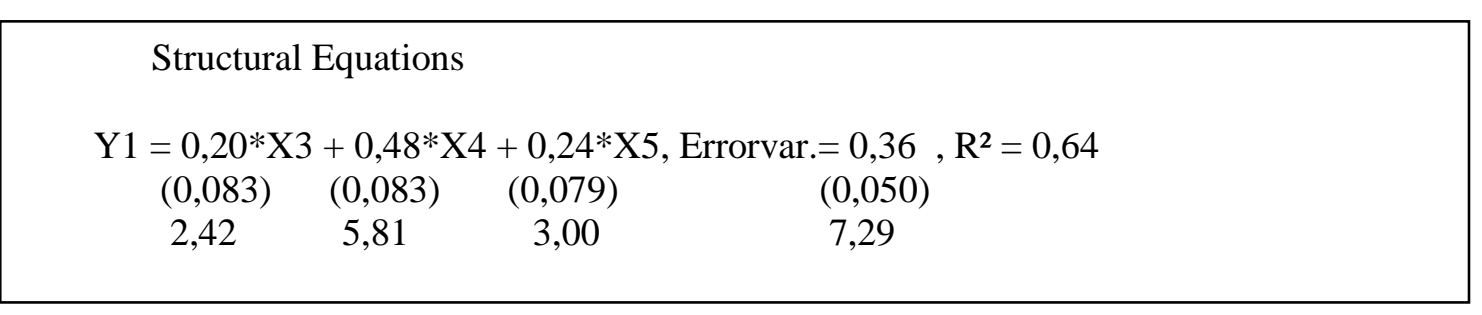

Gambar 3. Persamaan struktural hasil pendugaan parameter Model Dinamika Kelompok Tani Hutan

Gambar 3 menunjukkan hasil analisis yang berupa persamaan matematis hubungan antara peubah Y1 (dinamika kelompok tani hutan) yang merupakan fungsi dari X3 (peran SDM pemberdayaan, X4 (Keefektifan kepemimpinan kelompok), dan $\mathrm{X} 5$ (dukungan lingkungan). Dalam persamaan tersebut tercantum koefisien besarnya pengaruh peubah terhadap Y1. Angka paling bawah menunjukkan nilai-t yang menyatakan apakah besarnya koefisien pengaruh tersebut nyata secara statistik.

Berdasarkan gambar hasil analisis SEM Gambar 2 dan Gambar 3, rangkuman hubungan kausal (pengaruh langsung) antar peubah-peubah laten penelitian dan nilai- $t$ sebagai uji statistik disajikan pada Tabel 3 .

Tabel 3. Dekomposisi pengaruh antar peubah-peubah penelitian Dinamika Kelompok Tani Hutan

\begin{tabular}{llccccc}
\hline \multicolumn{2}{c}{ Hubungan Antar Peubah } & $\begin{array}{l}\text { Besarnya } \\
\text { Pengaruh }\end{array}$ & Nilai-t* & $\mathrm{R}^{2}$ \\
\hline X3 (Peran SDM Pemberdayaan) & $\rightarrow$ & Y1 (Dinamika Kelompok) & 0,20 & $2,42^{*}$ & \\
X4 (Keefektifan Kepemimpinan & $\rightarrow$ & Y1 (Dinamika Kelompok) & 0,48 & $5,81^{*}$ & 0,64 \\
Kelompok) & & & & & \\
X5 (Dukungan Lingkungan) & $\rightarrow$ & Y1 (Dinamika Kelompok) & 0,24 & $3,00^{*}$ & \\
\hline
\end{tabular}

Ket :

* nyata pada 0,05

Tabel 2 menunjukkan hubungan antar peubah-peubah penelitian, berupa koefisien besarnya pengaruh dan nilai-t (nyata tidaknya koefisien pengaruh), serta koefisien determinasi $\mathrm{R}^{2}$ dari tiga persamaan struktural dinamika kelompok tani hutan (Y1). Pengaruh langsung peran SDM pemberdayaan (X3), keefektifan kepemimpinan kelompok (X4) dan dukungan lingkungan (X5) masing-masing sebesar 0,20, 0,48 dan 0,24 . Ketiga koefisien pengaruh tersebut nyata pada $\alpha=0,05$. Model persamaan struktural dinamika kelompok (Y1) secara matematik adalah Y1=0,20 X3 + 0,48 X4 dan 0,24 X5. Secara bersama (simultan) pengaruh ketiga peubah tersebut pada kinerja dinamika kelompok yaitu 0,64. Hal ini mempunyai makna bahwa keragaman data yang bisa dijelaskan oleh model tersebut sebesar 64 persen, sedangkan sisanya sebesar 36 persen dijelaskan oleh peubah lain (yang belum terdapat di dalam model) dan error. Hal ini dapat dijelaskan sebagai berikut: (1) Peran SDM pemberdayaan secara langsung berpengaruh nyata terhadap dinamika kelompok tani hutan, berarti setiap peningkatan satu satuan peran SDM pemberdayaan akan meningkatkan dinamika kelompok tani 
hutan sebesar 0,20 satuan. (2) Keefektifan kepemimpinan kelompok berpengaruh nyata terhadap dinamika kelompok tani hutan, berarti setiap peningkatan satu satuan keefektifan kepemimpinan kelompok akan meningkatkan dinamika kelompok tani hutan sebesar 0,48 satuan. (3) Dukungan lingkungan berpengaruh nyata terhadap dinamika kelompok tani hutan, berarti setiap peningkatan satu satuan dukungan lingkungan akan meningkatkan dinamika kelompok tani hutan sebesar 0,24 satuan.

\section{Faktor-faktor yang Mempengaruhi Dinamika Kelompok}

Hasil penelitian menunjukkan bahwa dinamika kelompok tani hutan termasuk kategori rendah. Rendahnya dinamika kelompok tani hutan dipengaruhi secara nyata oleh kurang efektifnya kepemimpinan kelompok tani hutan, kurang kondusifnya dukungan lingkungan terhadap petani dan kurang optimalnya Mandor Perhutani menjalankan perannya sebagai pendamping petani. Besaran nilai koefisien persamaan struktural menunjukkan peubah mana yang pengaruhnya lebih besar terhadap dinamika kelompok. Keefektifan kepemimpinan kelompok tani berpengaruh paling besar terhadap dinamika kelompok. Kemudian disusul dukungan lingkungan terhadap petani. Peubah yang pengaruhnya paling kecil terhadap dinamika kelompok yaitu peran SDM pemberdayaan (Gambar 2).

Dinamika kelompok dalam penelitian ini merupakan kualitas interaksi dan perilaku anggota kelompok tani hutan serta perkembangan struktur dan pembagian tugas terhadap para anggotanya dalam mencapai tujuan kelompok diantaranya untuk peningkatan keberdayaan para anggotanya. Tiga indikator handal untuk mengukur dinamika kelompok dalam penelitian ini yaitu tujuan kelompok, struktur kelompok, dan fungsi/tugas kelompok (Tabel 1). Temuan lapangan menunjukkan bahwa tujuan kelompok tani kebanyakan belum dirumuskan dengan jelas, belum ditulis dan belum diberitahukan kepada para petani. Sehingga petani belum memahami secara utuh tujuan kelompok taninya. Demikian pula struktur kelompok, misalnya menyangkut pengambilan keputusan kelompok, kebanyakan anggota tidak dilibatkan untuk memutuskan hal-hal tentang kelompok. Yang terjadi, para pemimpin kelompok membuat keputusan kegiatan kelompok dan diberitahukan kepada anggotanya. Selain itu anggota secara umum memahami tugas dan tanggungjawab kelompok, dan memahami tata cara pelaksanaan tugas. Namun para petani belum memperoleh informasi tentang program dengan mudah dari kelompok. Fungsi tugas kelompok menyangkut sejauhmana manfaat pencapaian kelompok dirasakan anggota, manfaat tersedianya informasi dari kelompok, dan anggota memahami cara melakukan kegiatan dan hubungan antar kegiatan dalam kelompok. Fakta lapangan menunjukkan para petani belum merasakan manfaat yang optimal dari pencapaian tujuan kelompoknya. Lemahnya tiga indikator ini merupakan representasi dari masih rendahnya dinamika kelompok tani hutan.

Faktor pertama yang berpengaruh terhadap dinamika kelompok adalah keefektifan kepemimpinan kelompok tani hutan. Kurang efektifnya kepemimpinan kelompok tani hutan menyebabkan rendahnya dinamika kelompok tani hutan tersebut. Temuan lapangan menunjukkan bahwa keefektifan kelompok tani hutan termasuk kategori rendah. Hal ini menunjukkan bahwa kepemimpinan kelompok tani hutan masih belum efektif mendorong petani ke arah kelompok yang dinamis. Keefektifan kelompok 
yang rendah menyebabkan dinamika kelompok tani hutan menjadi rendah. Rendahnya keefektifan kepemimpinan kelompok disebabkan oleh kurangnya optimalnya pemimpin kelompok tani hutan melakukan perannya; kurangnya kemampuan perilaku kepemimpinan; dan gaya kepemimpinan kelompok yang belum mendorong petani ke arah kelompok yang dinamis. Peran-peran pemimpin kelompok meliputi : menjelaskan tujuan kelompok; menyediakan sarana dan prasarana kerja; memberikan semangat dalam bekerja; mendengarkan aspirasi petani dan memberikan saran pemecahan atas masalah petani. Perilaku kepemimpinan kelompok tani hutan meliputi kemampuan pemimpin kelompok dalam : mengenali anggotanya; membagi tugas secara merata dan proporsional; memberikan jalan keluar terhadap permasalahan anggota; mendorong anggota untuk mencapai tujuan kelompok; menyampaikan informasi secara efektif; menjaga kekompakan kelompok; menjaga keharmonisan kelompok; dan menjaga keterpaduan kelompok. Sedangkan gaya kepemimpinan kelompok menyangkut sejahmana pemimpin kelompok mampu : menampung aspirasi dan menjaga hubungan baik dengan anggota; membuat keputusan kelompok secara efektif; membagi tugas dan mengecek hasil kerja anggota; serta mengarahkan anggota untuk patuh pada aturan kelompok.

Kepemimpinan kelompok berpengaruh dengan dinamika kelompok sejalan dengan Hersey et al. (1996) yang menyatakan bahwa kepemimpinan adalah proses mempengaruhi aktivitas individu atau kelompok dalam usahanya mencapai tujuan pada situasi tertentu. Hal ini juga sesuai dengan Gani (2004) yang mensinyalir kepemimpinan Hasta Brata dalam konteks masyarakat Indonesia, dimana karakterstik kepemimpinan Hasta Brata ada delapan yaitu bintang (memberi inspirasi), matahari (memotivasi), bulan (memberi arah dan tuntunan), angin (menciptakan nuansa yang menyenangkan), api (kuat), awan (jujur dan adil), lautan (lapang) dan bumi (bisa diandalkan). Perilaku pemimpin kelompok yang mencerminkan hasta brata tersebut akan membuat para anggota merasa mendapatkan inspirasi, meningkat motivasi kerjanya, menjadi jelas arah dan tujuan kelompoknya sehingga kelompok semakin dinamis.

Faktor kedua yang berpengaruh terhadap dinamika kelompok adalah dukungan lingkungan terhadap petani. Fakta di lapangan menunjukkan bahwa dukungan lingkungan termasuk kategori rendah. Rendahnya dukungan lingkungan petani menyebabkan kurang dinamisnya kelompok tani hutan. Hal ini berarti bahwa lingkungan para petani kurang kondusif mendukung petani ke arah kelompok tani yang lebih dinamis. Dukungan lingkungan dalam penelitian ini merupakan tingkat kekuatan dan kualitas faktor-faktor di luar diri petani hutan yang mempengaruhi kehidupan petani. Dukungan lingkungan terdiri dari potensi pengembangan usahatani, adanya berbagai alternatif usaha yang bisa dilakukan kelompok dan adanya intervensi lingkungan sosial dari sesama anggota kelompok (Gambar 2). Kondisi lapangan menunjukkan bahwa potensi pengembangan usaha tani yang dimiliki kelompok tani hutan di dalam areal hutan yang dikerjasamakan antara LMDH dengan Perhutani sangat beragam. Diantaranya adalah adanya peluang budidaya tanaman bernilai tinggi pada lahan andil maupun lahan di bawah tegakan hutan (empon-empon, kapulogo, porang, rumput gajah dan lain-lain) dan peluang mengolah hasil tanaman tersebut agar mempunyai nilai jual lebih tinggi. Namun demikian kebanyakan petani belum mampu melihat peluang dan mengembangkan potensi tersebut. Berbagai alternatif usaha yang bisa dilakukan petani misalnya pengembangan ternak, memelihara ikan, berdagang, 
membuat barang kerajinan dan sebagai tenaga upahan (buruh). Fakta lapangan menunjukkan bahwa alternatif usaha tersebut sangat terbatas yang bisa dilakukan petani. Sebaliknya kondisi intervensi sosial relatif lebih memadai atau termasuk kategori sedang. Intervensi lingkungan sosial menyangkut aktivitas saling mengingatkan antar anggota, saling berbagi informasi dan saling belajar untuk kemajuan usahataniya.

Hasil penelitian ini menguatkan temuan Tampubolon (2006) yang menyatakan kedinamisan suatu kelompok usaha bersama (KUBE) pada masyarakat miskin dipengaruhi salah satunya oleh faktor lingkungan sosialnya. Lingkungan sosial ini meliputi peluang pasar, norma dan nilai budaya, hubungan kelompok dengan tokoh masyarakat, jaringan kerjasama dan ketersediaan sumberdaya.

Faktor ketiga yang berpengaruh terhadap dinamika kelompok adalah peran SDM pemberdayaan. Sumberdaya manusia pemberdayaan dalam penelitian ini adalah Mandor Perhutani sebagai tenaga lapangan Perhutani yang langsung berhubungan dengan kelompok tani hutan dalam berbagai kegiatan. Temuan penelitian ini menunjukkan kurangnya kemampuan Mandor Perhutani melaksanakan tugasnya sebagai pendamping petani dan kelompok tani menyebabkan rendahnya dinamika kelompok tani hutan. Peran Mandor yang harus dilakukan adalah : Mengembangkan partisipasi petani yang bermakna bahwa Mandor harus mampu mengajak petani ikut lebih aktif, membantu kelompok, menggali kebutuhan petani, menyadarkan akan kemampuan petani, dan mengobarkan semangat petani dalam melakukan kegiatan; (b) Membangun komunikasi dengan petani dan kelompok tani bermakna bahwa Mandor harus mampu menyediakan informasi program yang diperlukan petani, menjelaskan informasi program dengan baik kepada petani dan di hadapan kelompok tani; dan (c) Kesetaraan status sosial dengan petani mempunyai makna bahwa Mandor harus mampu membawakan dirinya di lingkungan sosial para petani sehingga petani merasa sejajar dengan mandor dan bisa menerima Mandor dengan baik (Gambar 2).

Hasil penelitian ini menguatkan Slamet (2003) yang menyatakan bahwa paradigma penyuluhan ke depan adalah pendekatan humanistik-egaliter sehingga petani ditempatkan sejajar dengan penyuluhnya. Hasil penelitian juga sejalan dengan hasil penelitian Tampubolon (2006) yang menyatakan bahwa faktor pola pemberdayaan yang diantaranya berupa pelayanan pendampingan berpengaruh terhadap kedinamisan kelompok usaha bersama (KUBE) pada masyarakat miskin.

\section{Model Dinamika Kelompok Tani Hutan}

Model adalah tiruan gejala yang akan diteliti. Sebagai tiruan, model hanya mengambil sebagian dari realitas. Model menggambarkan hubungan di antara variabelvariabel atau sifat-sifat atau komponen-komponen gejala tertentu. Dengan demikian model bukan teori walaupun bisa mengungkapkan atau melahirkan suatu teori. Tujuan utama model adalah mempermudah pemikiran yang sistematis dan logis. Model mempermudah analisis masalah (Rakhmat, 2004). Model dinamika kelompok tani hutan yang disusun dalam penelitian ini merupakan hasil kajian secara deduktif dan induktif. Kajian deduktif merupakan rumusan model awal yang merupakan hasil kajian secara teoretis atau model teoretis. Model teoretis diuji dengan hasil data empiris dari lapangan, sehingga disebut juga model hipotetik. Kajian induktif dilakukan melalui data 
empiris hasil survei dari lapangan. Analisis hubungan kausal menggunakan SEM dengan Program LISREL 8.72 yang telah diuraikan pada bagian terdahulu. Model sebagaimana Gambar 5 didasarkan kepada hasil respesifikasi model, sehingga sudah terpenuhi kecocokan model pengukuran, kecocokan keseluruhan model, dan kecocokan model struktural.

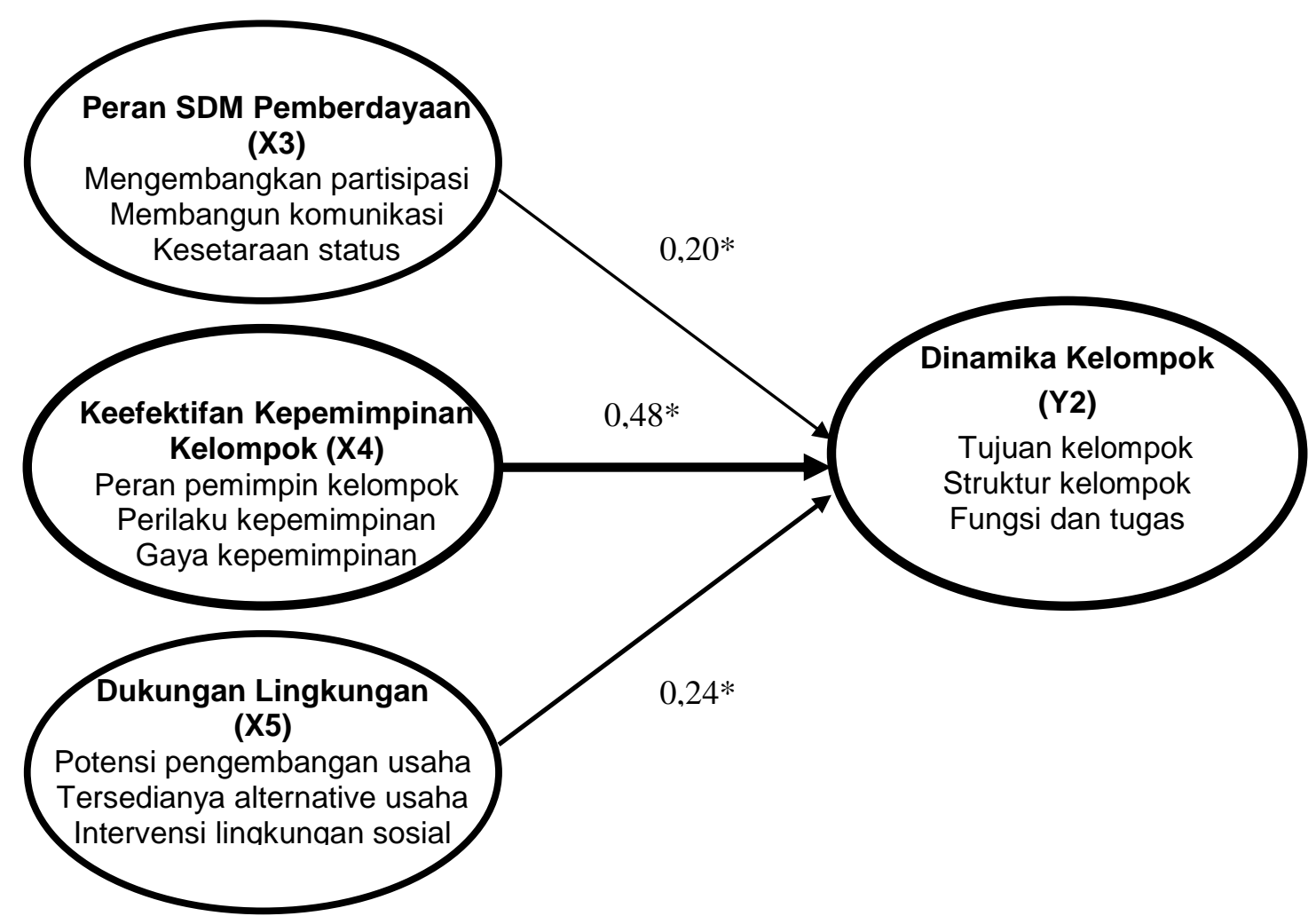

Gambar 5. Model Dinamika Kelompok Tani Hutan

Dinamika kelompok dalam model ini ditekankan pada kelompok tani hutan yang merupakan kelompok informal paling kecil pada tingkat komunitas petani. Dinamika kelompok mengandung makna adanya interaksi psikologis dan interdependensi diantara anggotanya. Unsur-unsur yang perlu dibenahi dalam dinamika kelompok dalam model ini ada tiga yaitu: tujuan kelompok, struktur kelompok, dan fungsi/tugas kelompok. Tujuan kelompok harus jelas, bisa dipahami para anggotanya, dan sejalan dengan tujuan anggotanya. Struktur kelompok menyangkut pengambilan keputusan yang melibatkan anggota, pembagian tugas yang dipahami anggota, tersedianya prosedur pelaksanaan tugas yang dipahami anggota, dan adanya arus informasi tentang kegiatan kelompok yang disampaikan kepada padra anggotanya. Fungsi dan tugas kelompok menyangkut kepuasan anggota atas tercapainya tujuan, informasi yang diterima anggota cukup jelas, para anggota paham dalam melakukan tugas-tugasnya dan para anggota memahami hubungan antar berbagai kegiatan kelompok. Dinamika kelompok bisa ditumbuhkan melalui tiga unsur berturut-turut dari yang terpenting yaitu keefektifan kepemimpinan kelompok, dukungan lingkungan dan peran sumberdaya manusia pemberdayaan.

Keefektifan kepemimpinan kelompok terdiri dari tiga unsur yaitu: peran pemimpin kelompok, perilaku kepemimpinan kelompok dan gaya kepemimpinan. Peran pemimpin kelompok menyangkut kemampuannya dalam menjelaskan tujuan, 
menyediakan sarana dan prasarana kerja, mendorong semangat kerja, mendengarkan keluhan anggota dan memberikan saran pemecahan masalah anggota. Perilaku kepemimpinan kelompok menyangkut sejauhmana pemimpin mengenal anggotanya, membagi tugas, memberikan jalan keluar atas masalah, mengajak bekerja lebih baik, menyampaikan informasi, menjaga kekompakan, menjaga suasana kelompok, dan mengarahkan keterpaduan berbagai kegiatan kelompok. Gaya kepemimpinan kelompok menyangkut kemampuan pemimpin kelompok untuk bergaul dengan para anggota, membuat keputusan, membagi tugas sesuai kemampuan anggota dan mengecek pelaksanaanya, mengarahkan terhadap aturan kelompok dan memberikan teguran.

Dukungan lingkungan merupakan kekuatan dan kualitas faktor dari luar diri petani hutan dalam menjalankan kerjasama pengelolaan hutan antara masyarakat dengan Perhutani. Dalam model ini dukungan lingkungan meliputi tiga unsur yaitu: potensi pengembangan usaha, tersedianya alternatif usaha dan intervensi lingkungan sosial. Potensi pengembangan usaha menyangkut sejauhmana petani melihat kesempatan budidaya tanaman bernilai tinggi pada andilnya, melihat peluang pengembangan berbagai usahatani lainnya, dan melakukan budidaya tanaman yang menguntungkan serta mengolah hasil tanaman pangan agar nilai jualnya lebih tinggi. Tersedianya alternatif usaha merupakan unsur dukungan lingkungan yang penting, meliputi ketersediaan alternatif bagi petani untuk mengembangkan ternak, budidaya ikan, berdagang, membuat barang kerajinan rumah tangga, dan bekerja untuk mendapatkan upah. Intervensi lingkungan sosial meliputi adanya perilaku saling mengingatkan di antara anggota kelompok untuk aktif dalam kegiatan, dan pembelajaran atau saling tukar menukar informasi sesama petani untuk memajukan usahataninya.

Sumberdaya manusia pemberdayaan atau istilah lainnya pendamping berdasarkan data penelitian lapangan yaitu Mandor Perhutani. Mandor sebagai tenaga lapangan yang langsung berhubungan dengan petani, mempunyai tugas pokok tertentu seperti bidang tanaman, bidang pemeliharaan, bidang tebangan, bidang sadapan getah Pinus, dan ada yang khusus membidangi PHBM yaitu Mandor PHBM. Mandor PHBM ini jumlahnya sedikit, karena pada tingkat BKPH biasanya hanya ada satu orang. Sedangkan Mandor bidang lain jumlahnya ada beberapa orang untuk tiap RPH atau tingkat desa. Dalam model ini, peran pendamping terdiri dari tiga yaitu: mengembangkan partisipasi petani, membangun komunikasi, dan kesetaraan status sosial dengan petani. Mengembangkan partisipasi berarti pendamping mampu mengajak petani turut serta dalam sosialisasi program, membantu kegiatan kelompok, menggali kebutuhan dan kemampuan petani, dan membuat petani bersemangat menjalankan program. Membangun komunikasi berarti pendamping mampu menyediakan berbagai informasi yang diperlukan, menjelaskan mengenai program terhadap petani dan kelompok tani. Kesetaraan status sosial dengan petani berarti pendamping harus berperilaku di tengah masyarakat sehingga petani memandang kedudukan pendamping sejajar dengan mereka dan bisa diterima dengan baik bila berada di lingkungan sosialnya. 


\section{Kesimpulan}

Kondisi peubah-peubah penelitian yaitu: (1) Potensi sumberdaya individu petani yaitu : luas lahan garapan tiap keluarga petani rata-rata 1,25 ha; pengalaman berusaha tani rata-rata 21 tahun dan 9 tahun terakhir mengolah lahan hutan; umur rata-rata 43 tahun; pendapatan keluarga per bulan rata-rata $\mathrm{Rp} 1.061 .077$,- dan sepertiganya berasal dari mengelola sumberdaya hutan; pendidikan formal petani mayoritas (79\%) sampai SD; pendidikan non formal termasuk kategori jarang mengikuti pelatihan kehutanan; motivasi berkelompok termasuk sedang; dan keinovatifan petani secara keseluruhan termasuk rendah. (2) Ketepatan proses pemberdayaan termasuk rendah dengan skor 26. Kondisi ketepatan proses pemberdayaan di KPH Kedu Selatan relatif lebih tinggi dan berbeda nyata dengan dua lokasi penelitian lainnya. (3) Peran SDM pemberdayaan termasuk dalam kategori rendah dengan skor 65 dan terdapat perbedaan yang nyata diantara tiga lokasi penelitian. Peran SDM pemberdayaan pada KPH Kedu Selatan relatif lebih tinggi disusul KPH Gundih dan paling rendah kondisi di KPH Pekalongan Timur. (4) Keefektifan kepemimpinan kelompok termasuk dalam kategori rendah dengan skor 62 dan terdapat perbedaan yang nyata diantara tiga lokasi penelitian. Kepemimpinan kelompok tani di KPH Kedu Selatan relatif lebih efektif, disusul KPH Gundih dan paling rendah KPH Pekalongan Timur. (5) Kondisi dukungan lingkungan termasuk dalam kategori rendah dengan skor sebesar 62. Dari tiga lokasi penelitian, terdapat perbedaan yang nyata tentang kondisi dukungan lingkungan. Kondisi dukungan lingkungan di KPH Kedu Selatan relatif paling tinggi, disusul kondisi di KPH Pekalongan Timur dan paling rendah di KPH Gundih. (6) Dinamika kelompok tani hutan secara umum termasuk kategori rendah dengan skor sebesar 65. Kondisi dinamika kelompok tani hutan berbeda secara nyata antar tiga lokasi penelitian. Dinamika kelompok tani hutan di KPH Kedu Selatan termasuk 'sedang'dengan skor rataan sebesar 67, sedangkan dinamika kelompok tani hutan di KPH Gundih termasuk rendah namun lebih baik dibandingkan kondisi di KPH Pekalongan Timur.

Rendahnya dinamika kelompok tani hutan dipengaruhi oleh: (a) kurang efektifnya kepemimpinan kelompok tani hutan; (b) kurang kondusifnya dukungan lingkungan terhadap peningkatan kehidupan para petani; dan (c) kurangnya kemampuan tenaga Mandor Perhutani sebagai pendamping petani dan kelompok tani.

Model yang efektif untuk peningkatan dinamika kelompok tani hutan yaitu melalui peningkatan keefektifan kepemimpinan kelompok, peningkatan dukungan lingkungan dan optimalisasi peran tenaga Mandor Perhutani sebagai pendamping petani dan kelompok tani.

\section{DAFTAR PUSTAKA}

Gani, Darwis Suharman. 2004. Leadership in Indonesia : A Case for Managing Relationship within Organizations. dalam Dean Tjosvold \& Kwok Leung, editor. Leading in High Growth Asia - Managing relationship for teamwork and change. Singapore: World Scientific.

Hersey, Paul, Kenneth H. Blanchard, Dewey E. Johnson. 1996. Management of Organizational Behavior. Ed. Ke-7. Upper Saddle River, NJ: Prentice Hall. 
Kusnendi. 2008. Model-model Persamaan Struktural, Satu dan Multigroup Sampel dengan Lisrel. Bandung: Penerbit Alfabeta.

Mulyadi. 2008. Faktor-faktor yang berpengaruh dalam Program Gerakan Nasional Rehabilitasi Hutan dan Lahan (Gerhan): Studi kasus di Kecamatan Padang Cermin dan Kecamatan Natar, Kabupaten Lampung Selatan. Tesis. Yogyakarta: Program Pascasarjana Fak. Teknik UGM.

Rakhmat, Jalaluddin. 2004. Metode Penelitian Komunikasi (Dilengkapi contoh analisis statistik). Cet. 11. Bandung : PT. Remaja Rosdakarya.

Sardjono, Mustofa Agung. 2004. Mosaik Sosiologis Kehutanan: Masyarakat Lokal, Politik dan Kelestarian Sumberdaya. DEBUT Press: Yogyakarta.

Slamet, Margono. 2003. Paradigma Baru Penyuluhan Pertanian di Era Otonomi Daerah. Di dalam: Ida Yustina dan Adjat Sudradjat, editor. Membentuk Pola Perilaku Manusia Pembangunan. Bogor : IPB Press.

Suharjito, Didik., Aziz Khan, Wibowo A. Djatmiko, Martua T. Sirait, Santi Evelyna. 2000. Karakteristik Pengelolaan Hutan Berbasiskan Masyarakat. Yogyakarta: Aditya Media.

Tampubolon, Joyakin. 2006. Pemberdayaan Masyarakat Melalui Pendekatan Kelompok: Kasus Pemberdayaan Masyarakat Miskin melalui Pendekatan Kelompok Usaha Bersama (KUBE). Disertasi. Bogor: Sekolah Pascasarjana IPB.

Thompson, H. 1999. Social forestry : an analysis of Indonesian forestry policy. Journal of Contemporary Asia 29(2):187-201. http://www.proquest.umi.com/pqdweb?. Diakses pada 16-08-2006.

Wijanto, Setyo Hari. 2008. Structural Equation Modelling dengan LISREL 8.8: Konsep dan Tutorial. Yogyakarta: Graha Ilmu. 